\title{
The Effects of Instruction Dimension, Environmental Dimension and Student Trust Toward Indonesian Student's Satisfaction in Online Learning of SAP (ERP)
}

\author{
Lita Kusumasari $^{1 \bowtie}$, Prima Rosita Arini ${ }^{2}$, Jay Rajasakera ${ }^{3}$, Badr Alsolami ${ }^{4}$ \\ Sekolah Tinggi Ilmu Ekonomi YKPN Yogyakarta, Indonesia ${ }^{1,2}$ \\ Institute of International Strategy, Tokyo International University, Tokyo, Japan ${ }^{3}$ \\ Department of Islamic Architecture, Umm Al-Qura University, Mecca, Saudi Arabia ${ }^{4}$ \\ e-mail: 1kusumasari@yahoo.com
}

\begin{abstract}
Student's satisfaction has important role in improving student's performance and the academic institution quality. Due to the outbreak of Covid-19, an academic institutes shifted their traditional learning methods to online classes. In teaching SAP, which is prominent software for Enterprise Resource Planning, the student's satisfaction requires further attention because of the subject complexity; in terms of delivery mode and infrastructure requirements. Hence, this paper aims at examining the student's satisfaction for SAP courses during the outbreak. The examination includes relationship between factors that include instructor's dimension, environmental dimension, student trust and student satisfaction. A total of 332 responses were collected from students who were involved in SAP subjects and experienced the transition of traditional teaching to online teaching of the subject. The data was analyzed using SPSS for descriptive analysis and AMOS for Structural Equation Modeling (SEM). Internal consistency of the research instrument, Kaiser-Meyer-Olkin measure of sampling adequacy and exploratory factor analysis revealed that the research instrument was suitable. The findings indicate that instruction dimension significantly affected environmental dimension, student trust and student satisfaction. Environmental dimension significantly affected student trust and student trust significantly affecting student satisfaction. Student trust is mediating the relationship between instruction dimension and environmental dimension toward student satisfaction. Moreover, the results show that instructor plays dominant role toward student trust and student satisfaction. The learning environment, which include interaction between students and lecturer, enhances the student to overcome difficulties while learning online. These findings are critical in understanding the students' satisfaction in online learning and contribute in improving the learning environment.
\end{abstract}

Keywords: Enterprise Resource Planning, SAP, online learning, user satisfaction, user trust 


\section{INTRODUCTION}

Any organization need resource planning to be excellent. System, Application and Product (SAP) is the most prominent software, pioneer, and the largest firm for Enterprise Resource Planning (ERP) in the world (Chien \& Tsaur, 2007). To be link and match with the real business, many universities integrate SAP into curriculum. It is believed to beneficial students by give hands-on experience with a live of ERP system (Kirkham \& Seymour, 2005). ERP E-learning model provides an innovative and effective education (Dalveren, 2014).

The SAP ERP System becomes current trends in E-Learning Assessment (Lara et al., 2020). Having knowledge of various roles in ERP system could increase communication and efficiency in a company (Wilson \& Lindoo, 2011). The success of SAP courses will enhance the opportunity for students to be easily working in company using SAP.

A live of SAP needs instructors, students, and infrastructure to be aligned and synchronize. SAP is running online under SAP server (not at a university). The network, internet and computers must be stable and good one. A basic computer literate is a must for students. The enterprise resource planning is an integrated software that based on business knowledge, financial and management accounting, logistics, human resource management, and system. Lecturer has to master on the knowledge and could explain to the students. Students must overcome all the challenges to excel in SAP. Even for traditional class, this course has been quite demanding.

Due to Covid-19, there is shift learning for SAP from traditional to online class. There are two problems arise, SAP and online class. First, SAP R/3 is a complicated program. Inappropriate implementation will lead to failure and student dissatisfaction (Wilson \& Lindoo, 2011). Second, the online program creates more problems than solution and the effectiveness of online learning will reduce for advanced accounting compare to fundamental accounting courses (Engel, 2019).

Although SAP makes frustration, students have positive perceptions of the usefulness, ease of use, and intention to use the SAP (Irriberri et al., 2014). Teaching elearning requires effort on proposed methods, strategies to deliver, and procedures to achieve effective and efficient processes (Bulut, 2019).

Student's satisfaction plays a major role in improving student's performance and the academic institution quality. The student's satisfaction requires further attention because of the subject complexity; in terms of delivery mode and infrastructure requirements. Hence, this paper aims to examining the student's satisfaction for SAP courses during the outbreak. The examination includes relationship among factors that include instructor dimension, environmental dimension, student trust and student satisfaction.

This research is different from previous scholars. First, in term on environment context. The research is in Indonesia. One of the studies is the experience of Victoria University while was offering ERP education through a strategic alliance with SAP (Hawking \& McCarthy, 2001). The other study about the lesson learned to integrate ERP into curriculum was in Cape town University, South Africa (Kirkham \& Seymour, 2005). The university could use the open source that is Open ERP® to overcome the complexity of SAP (Ayyagari, 2011). Regis University in USA try to implement with big bang approach into online MIS course using SAP $\mathrm{R} / 3$. It leads to failure (Wilson \& Lindoo, 2011).

Second, the previous research was on the traditional class or pure on online class. This research undergoes under traditional class for half semester and another half semester was on online class. Students could compare their experiment between offline and online. This will give better understanding. Third, student satisfaction 
model has been exposed on many research, but rarely on the SAP class.

Based on those findings, we conclude there are major methodological limitation in studies, inconsistence results across studies, inadequate comparisons, and inadequate findings. Limited study has taken place in Indonesia and no respondents that taken both traditional and online class.

\section{Flow Theory}

The original concept of flow is defined as the holistic sensation that people feel when they act with total involvement. When an individual feel so satisfying doing an activity, the individual will repeat the activity continuously. That is the state of flow (Csikszentmihalyi, 1990). The learning purpose is to understand the circumstances and develop the meaning into experience. When the formal education end, then the different kind of education start and motivated intrinsically.

The e-learning ERP training course is an education-oriented-web-based technology that flow experience happen. An individual is doing it with total passion could be used as a valid metric in the flow experience. There was a logical foundation to identifying factors that can contribute to the flow experience to develop the research model and hypotheses in the e-learning environment (Choi et al., 2007).

\section{Hypoteses}

The ability of a lecturer in explaining teaching materials is the main key so that students believe that the lesson can give some benefit in another day. Lecturers should be able to create a fun learning environment so that students will be more excited to join the class. Another thing that should be of concern is that lecturers are open to criticism and suggestions given by students. So that lecturers will continue to improve the learning methods so that students increasingly believe that these lessons can indeed provide benefits in the future. Volery and Lord (2000) conducted a study which showed that the instructor dimension had a positive and significant impact on student trust. They state that instructor technical competence has an important part as a knowledge direction. Instructor states clear goals and provides technical skill for e-learning. Students are guided on how to handle the e-learning systems. The instructor's guide the technology to have a positive relationship with students' attitude and cognitive engagement (Webster \& Hackley, 1997). Based on previous research, there can be a hypothesis as follow:

$\mathrm{H}_{1}$ : Instruction Dimension will significantly affect student trust.

Teaching and social presence are important factors to enhance learning quality driven by the instructor (Ladyshewsky, 2013). The instructor's attitude towards e-learning is the key of the effective and successful implementation. It could be stated that student satisfactions are influenced by teacher's teaching style or his execution while taking of an online eEducation.

Volery \& Lord (2000) stated that the interactive communication among all student and instructor and also timely feedback are called interaction. The interactivity in a web environment should be prompt interaction and timely feedback to students (McIntyre \& Wolff, 1998). Interaction is needed because without interaction environment to learn can be so boring and it can make students hard to understand about the topic. The other research shown that student attitudes affected by interaction amongst students and instructor while conducting e-learning (Ritchie \& Newby, 1989). The way of interaction is strongly influence students' attitude in e-learning (Sun \& Hsu, 2005). The proposed hypothesis as follow:

$\mathrm{H}_{2}$ : Instruction Dimension will significantly affect environmental dimension

The instructor's attitude has a positive effect on perceived student satisfaction 
toward e-learning (Sun et al., 2008; Gray \& DiLoreto, 2016). The instructor is the main factor toward student satisfaction. The approach to conduct teaching in a friendly situation and present quality and useful content will contribute to student satisfaction in e-learning (Noorulhasan et $a l, 2017)$. Some students feel that e-learning makes study easier (Salamat et al, 2018). It means that the greatest impact on student satisfaction is educational system quality.

This shows that collaborative learning tools, personalization, etc. play an important role in achieving student satisfaction. Previous research finding about ERP e-learning stated that the models provide an innovative and effective education. E-learning model based on web technology can maximized student learning outcome due to the flexibility compare to ordinary learning (Dalveren, 2014).

$\mathrm{H}_{3}$ : Instruction Dimension will significantly affect student satisfaction

Support for student learning will related to overall satisfaction of the online course. Student perceived supports are instructional, peer, and technical support. Student perceived support empirically was positively associated with student satisfaction. The finding result showed that there was a correlation between course satisfaction and final scores. Not all of each category of students' perception of support was correlated with student final scores (Lee et al., 2011).

Relationship between lecturer and students have an impact in classroom management and affect learning progress. Lecturers should have some skills to observe the students to know and understanding them (Leitão \& Waugh, 2007). Consistency to maintain trust is not simply about gaining student trust, but also being consistent in your actions and reaction to develop the mutual respect that is necessary to nourish and maintain a trusting teacher-student relationship. The cognitive complexity and intellectual stimulation play as significant factor in student success in e-learning (Gillet-Swan, 2017).

$\mathrm{H}_{4}$ : Environmental Dimension will significantly affect student trust

The success factor dimensions of elearning system are student, design and contents, system and technological dimensions, and institutional management (Noorulhasan et al, 2017). The students, instructors, courses, technology, design, and environmental are factors influencing learner satisfaction. The other critical factors are student computer anxiety, flexibility e-learning course, instructor attitude, course quality, perceived usefulness, perceived ease of use, and diversity in assessments toward student satisfaction (Sun et al, 2008).

There are 2 modes of communication in e-learning. First is synchronous mode and second is asynchronous mode. The asynchronous mode had additional opportunities for interaction and participation for externally enrolled students, it worked particularly in relation to group activities (Gillet-Swan, 2017). From the model both facilitator and students can have some benefits such as real time help while in class, the adaptability for each student and the greater participatory role in the e-learning (Zapalska \& Brozik, 2007).

$\mathrm{H}_{5}$ : Student trust will significantly affect student satisfaction

When trust arises in students, they will feel satisfied because they got the elearning lesson. So, it can be said that the sense of satisfaction felt by the student does not present itself. The feeling of satisfaction arises because they have previously had experiences that make them compound that the e-learning is beneficial and at the end, they are able to apply the knowledge. Without trust, the knowledge will not be conveyed properly to students. When there is no trust, students will always wonder about the quality of e-learning.

$\mathrm{H}_{6}$ : Student trust is mediating toward student satisfaction 


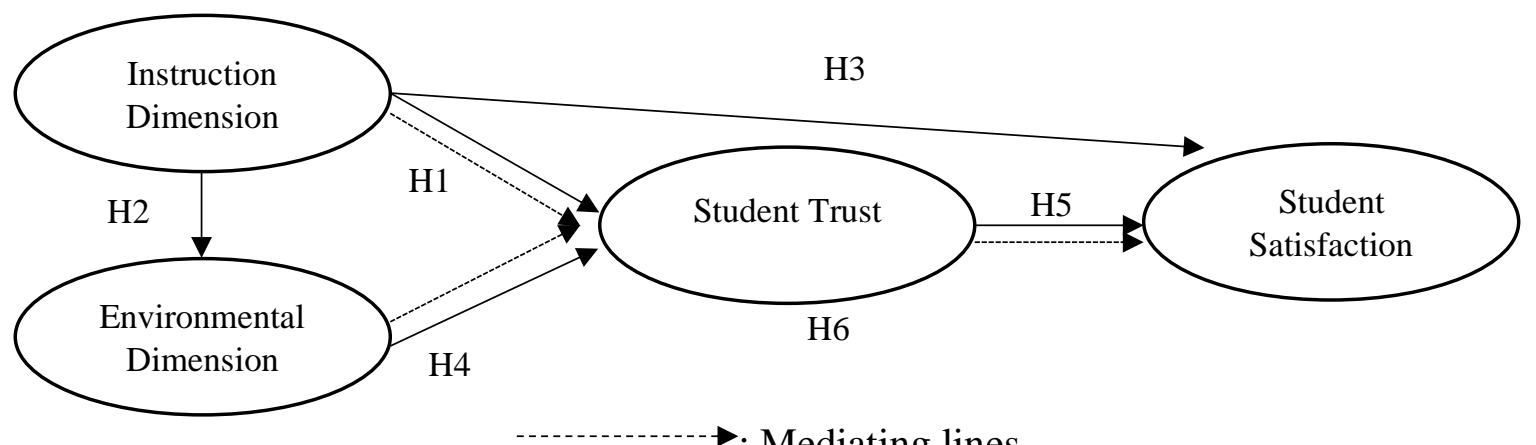

Figure 1. The Conceptual Model of The Research

Table 1. Statements on Survey

\begin{tabular}{|c|c|c|}
\hline Category & Factors & Previous Research \\
\hline Instruction & Instructor attitude toward e-learning: & (AL-Rahmi, et al., \\
\hline \multirow[t]{5}{*}{ Dimension } & 1. Lecturer explains the theory of ERP clearly & 2018) \\
\hline & 2. Lecturer explains transaction practices of SAP clearly & (Sun, Tsai, Finger, \\
\hline & 3. Lecturer gives solution while trouble & Chen, \& Yeh, 2008) \\
\hline & 4. Lecturer makes sure that I can follow the practices & (Gray \& DiLoreto, \\
\hline & 5. I learn from lecturer's feedback & 2016) \\
\hline Environmental & Learner perceived interaction with others: & (AL-Rahmi, et al., \\
\hline \multirow[t]{4}{*}{ Dimensions } & 1. I can communicate with my classmates & 2018) \\
\hline & 2. I communicate with my lecturer frequently & (Sun, Tsai, Finger, \\
\hline & 3. I can get feedback from my classmates & Chen, \& Yeh, 2008) \\
\hline & & $\begin{array}{l}\text { (Gray \& DiLoreto, } \\
\text { 2016) }\end{array}$ \\
\hline Student & 1. Learning SAP is enjoyable & (Duan, He, Feng, Li, \\
\hline \multirow[t]{4}{*}{ Satisfaction } & 2. Learning SAP fits my need & $\& \mathrm{Fu}, 2010)$ \\
\hline & 3. I will recommend SAP to others & (Holsapple \& Lee- \\
\hline & 4. I am satisfied with methods of SAP & Post, 2006) \\
\hline & 5. I am satisfied with contents of SAP & $\begin{array}{l}\text { (Gray \& DiLoreto, } \\
\text { 2016) }\end{array}$ \\
\hline \multirow[t]{4}{*}{ User Trust } & 1. Learning SAP has a good reputation & (Dorobai, Corbea, \& \\
\hline & 2. Learning SAP is accountable & Muntean, 2019) \\
\hline & $\begin{array}{l}\text { 3. Learning SAP provides ethics policies that outlines rules, } \\
\text { regulation, guidelines, and prohibitions }\end{array}$ & \\
\hline & 4. Learning SAP protects information related to student records & \\
\hline
\end{tabular}

\section{RESEARCH METHOD}

\section{Research Participants and Procedure}

An online survey was distributed to the students of STIE YKPN Business School, Yogyakarta in Indonesia on May 5-20, 2020. The research used purposive sampling technique. Respondents were from SAP Classes (Fundamental, Logistics, and Accounting) of STIE YKPN run in Semester 2 of Academic Years of 2019/2020. A total of 332 responses were collected from students who were involved in SAP subjects and experienced the transition of traditional teaching to online teaching of the subject. Total students who taken SAP subject are five hundred and sixty-eight (568) students. The responds rate is $58.45 \%$. Based on Krejcie and Morgan (1970) for 600 population, the need of samples are 234, so it can be said that the number of samples are suitable for this research.

Pre and pilot testing of the measures were conducted to validate the instrument. The pre-test involved four experts that were SAP's lecturers and 30 students who had 
taken the ERP classes. They were asked to comment on the instruments, the statement of the questions, and any ambiguity or difficulties with the questionnaire. The survey included 25 items on 5-point Likert scale (from 1- strongly disagree to 5strongly agree).

\section{Research Measurements}

There are four variables (instructor dimension, environmental dimension, student trust, and student satisfaction) used for this research. The survey statement is taken from various sources. The instruction dimension is measured by course delivery in class in terms of theory and SAP practice and consists of 5 items. The environmental dimension measured class interaction between students and the feedback and consists of 3 items. Student trust is based on the reputation and reliability of SAP and consists of 4 items. Student satisfaction measured that SAP is suitable with the demand and satisfaction so students will recommend to others and consist of 5 items. So, the total item on the survey is 17 statements. The sources and the statement could be found in Table 1 .

SEM includes two main sub-models: the measurement model and structural models. Hair et al. (2010) defined the measurement model as a SEM model that (1) specifies the indicators for each construct, and (2) enables an assessment of construct validity. SEM is used in this research because errors in each observation are not ignored but are still analyzed so that SEM is more accurate for analyzing questionnaire data that involving perceptions.

\section{Reliability Test}

The reliability of the constructs was tested based on the results of examining the measurement model. To test the reliability using Cronbach Alpha. Cronbach Alpha values indicated the reliability of the measurement model, the recommended level of Cronbach's alpha is 0.70 , and 0.60 is acceptable for exploratory research (Hair et al., 2010). The values for this indicator were between 0.811 and 0.909 (see table 2). These values confirm that the constructs achieved a good level of reliability.

Table 2. Reliability Test

\begin{tabular}{lc}
\hline \multicolumn{1}{c}{ Indicators } & Cronbach Alpha \\
\hline User Trust & 0.904 \\
Instruction Dimension & 0.909 \\
Environmental Dimension & 0.811 \\
Student Satisfaction & 0.903 \\
\hline
\end{tabular}

Table 3. KMO and Bartlett's Test

\begin{tabular}{llc}
\hline $\begin{array}{c}\text { Kaiser- } \\
\begin{array}{c}\text { Meyer- } \\
\text { Olkin }\end{array}\end{array}$ & \multicolumn{1}{c}{$\begin{array}{c}\text { Measure of Sampling } \\
\text { Adequancy }\end{array}$} & $\mathbf{0 . 9 0 6}$ \\
\hline Bartlett's & Aprrox. Chi-Square & $4,059.058$ \\
Test of & Df & 136 \\
Sphericity & Sig. & 0.000 \\
\hline
\end{tabular}

Table 4. Analysis Factor Test

\begin{tabular}{|c|c|c|c|c|}
\hline \multicolumn{5}{|c|}{ Pattern Matrix } \\
\hline & \multicolumn{4}{|c|}{ Component } \\
\hline & 1 & 2 & 3 & 4 \\
\hline UT1 & & & 0.886 & \\
\hline UT2 & & & 0.851 & \\
\hline UT3 & & & 0.856 & \\
\hline UT4 & & & 0.804 & \\
\hline ID1 & 0.887 & & & \\
\hline ID2 & 0.862 & & & \\
\hline ID3 & 0.891 & & & \\
\hline ID4 & 0.852 & & & \\
\hline ID5 & 0.716 & & & \\
\hline ED1 & & & & 0.851 \\
\hline ED2 & & & & 0.806 \\
\hline ED3 & & & & 0.855 \\
\hline SS1 & & 0.771 & & \\
\hline SS2 & & 0.793 & & \\
\hline SS3 & & 0.767 & & \\
\hline SS4 & & 0.873 & & \\
\hline SS5 & & 0.857 & & \\
\hline
\end{tabular}

\section{Validity Test}

The research instrument has to be tested for internal consistency. Kaiser-Meyer-Olkin is used to measure sampling adequacy while exploratory factor analysis is used to measure the suitable of instrument's statements. Based on those tests that could be seen on table 3, the research passed. The KMO test allows us to ensure that the data we have are suitable to run a Factor Analysis and therefore determine whether we have in fact measured what we intended 
The Effects of Instruction Dimension, ... Learning of SAP (ERP) (Kusumasari, Arini, Rajasakera, Alsolami)

to measure. The statistic that is computed is a measure of 0 to 1 . Based on the results of the KMO test, it can be seen that KMO have a high value because the KMO value is 0.906 and significant rate is 0.000 generally indicate that a factor analysis may be useful with the data. The results of pattern matrix shows that the question items in the questionnaire have been grouped into 4 groups and all are grouped according to the variables.

Table 5. Model Fits

\begin{tabular}{llc}
\hline \multicolumn{1}{c}{ Items } & $\begin{array}{c}\text { Rules of } \\
\text { Thumb }\end{array}$ & $\begin{array}{c}\text { Fit } \\
\text { Indices }\end{array}$ \\
\hline Chi Square & $<30$ & 1.638 \\
RMSEA & $<0.08$ & 0.044 \\
GFI & $>0.9$ & 0.998 \\
AGFI & $>0.9$ & 0.975 \\
CMIN & $<2$ & 1.638 \\
NFI & $>0.9$ & 0.996 \\
CFI & $>0.9$ & 0.999 \\
TLI & $>0.9$ & 0.991 \\
\hline
\end{tabular}

\section{Structural Model}

The fit of the proposed structural model was evaluated. The model fit indicators were: Chi Square 1.638, CMIN/DF 6.638, GFI
0.998, AGFI 0.975, CFI 0.999, and RMSEA 0.044 . These results show that the model achieved a good fit. The result stated on Table 5.

\section{RESULT AND DISCUSSION The Structural Model}

The paths among the constructs in this model are testing. As shown in table, the results of the regression analysis confirmed the significant impact of all the hypothesis. As hypothesized one, instruction dimension had a positive effect on student trust ( $\beta=$ $+0.271, p=0.003<0.05)$. The result supported H1. Instruction dimension had a positive effect on environmental dimension $(\beta=+0.652, p=*<0.05)$. The result supported H2. Instruction dimension had a positive effect on student satisfaction $(\beta=$ $+0.159, \mathrm{p}=0.008<0.05)$. The result supported H3. H4 suggested a positive effect of environmental dimension on student trust $(\beta=+0.501, \mathrm{p}=*<0.05)$. H4 was therefore supported. As hypothesized, a positive effect of student trust on student satisfaction was found $(\beta=+0.706, p=*<$ 0.05). H5 was also supported. See Table 6.

Table 6. Hypothesis

\begin{tabular}{lcc}
\hline \multicolumn{1}{c}{ Hypothesis } & Estimate & P-value \\
\hline H1 = Instruction Dimension will significantly affect student trust & 0,271 & 0,003 \\
H2 = Instruction Dimension will significantly affect environmental dimension & 0,652 & $*$ \\
H3 = Instruction Dimension will significantly affect student satisfaction & 0,159 & 0,008 \\
H4 = Environmental Dimension will significantly affect student trust & 0,501 & $*$ \\
H5 = Student trust will significantly affect student satisfaction & 0,706 & $*$ \\
\hline
\end{tabular}

\section{Hypothesis Mediating}

The results of this study indicate that student trust is able to mediate toward student's satisfaction. This mediation relationship can be seen from comparing the value of direct and indirect effect.

Table 7. Mediating Analysis

\begin{tabular}{ll}
\multicolumn{1}{c}{ Effect } & \multicolumn{1}{c}{ Value } \\
\hline Direct & 0.272 \\
Indirect & 0.328 \\
\hline
\end{tabular}

If the value of direct effects is smaller than the value of indirect it may be said is capable of mediating variables. The result shows that direct effects have smaller value $(0,272)$ than indirect effect $(0,328)$. So, it can be concluded that student trust mediating toward student's satisfaction.

\section{Path Analysis}

The results of data analysis using SEM are shown in Figure 2. These results show the relationship between variables and also the error factor in the variables (shown by e1 to e7). The instruction dimension toward student trust path was significant, this can be seen from the significance value is 0.03 which is smaller than 0.05 . The instruction dimension toward environmental 
dimension path was also significant, the result can be seen from the significance value is $*(0,0000)$ which is smaller than 0.05 . The result showed that instruction dimension toward student satisfaction path was found, it shown that instruction dimension has significant path towards student satisfaction. Result from analysis shown that significance value is 0,008 which is smaller than 0.05. The environmental dimension toward student trust path was demonstrated and the result are the same as the previous hypothesis. This can be seen from the significance value is $*(0,0000)$ which is smaller than 0.05 . The student trust toward student satisfaction path was significant, result from analysis shown that significance value is $*(0,0000)$ which is smaller than 0.05 . The effect of all hypotheses is positive. The result is shown on Figure 2.

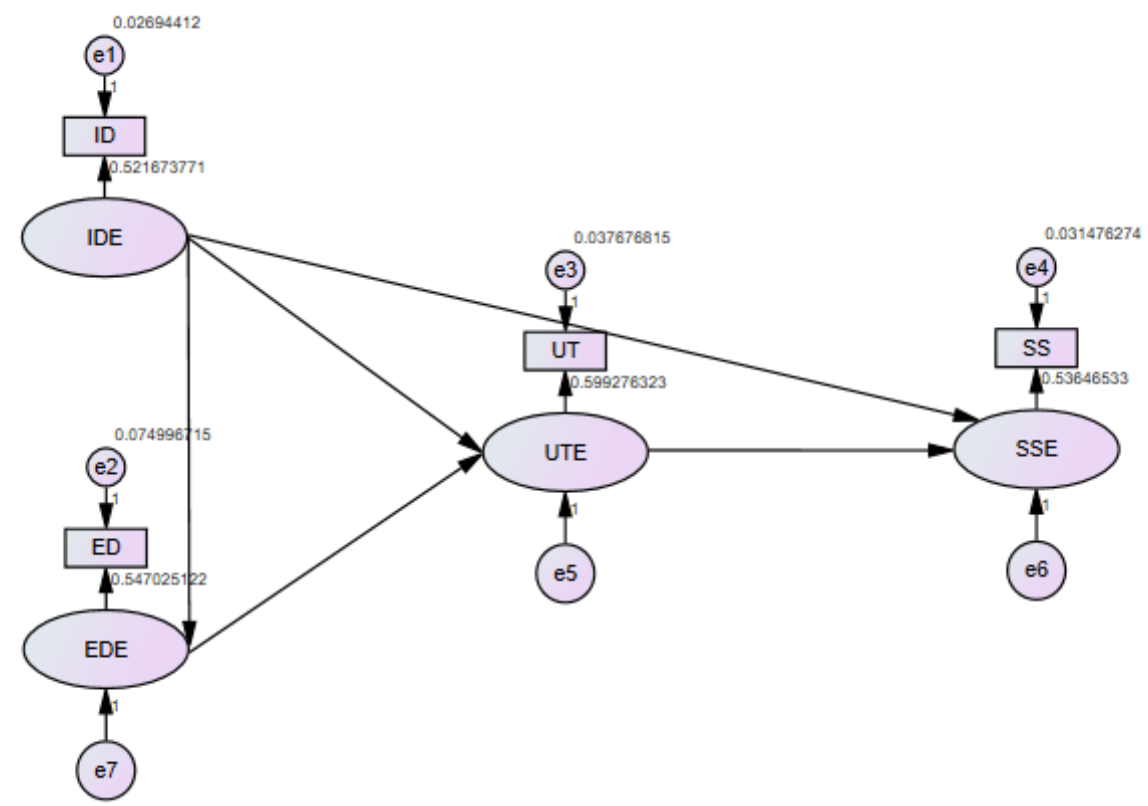

Figure 2. Path Analysis

\section{Instruction Dimension will Significantly Affect Student Trust}

Based on the results obtained, it appears that the instruction dimension has a significant effect on student trust. The results of this study are in accordance with the research of Volery and Lord (2000) which states that instructor technical competence has an important role as being teach the knowledge and also as a navigator. The instructor will state purpose and share technical skill for elearning and also the system. In this case is SAP system. The instructor will control technology and have a positive relationship with students' attitude towards using a specific technology for distance learning as well as with cognitive engagement (Webster \& Hackley, 1997).

\section{Instruction Dimension will Significantly Affect Environmental Dimension}

The results showed that the instruction dimension has a positive and significant effect on the environmental dimension. Interaction involves the interactive abilities of an e-learning system amongst all students and the instructor, and direct/timely feedback from the system (Volery \& Lord, 2000). McIntyre and Wolff (1998) noted that e-learning is challenging but can be beneficial most with fast and prompt interaction and timely feedback to students. The student attitudes in e-learning can be significantly affected by interaction amongst students and instructor (Ritchie \& Newby, 1989). The ability to interact strongly influences students' attitude, therefore, the ways of interaction should be 
The Effects of Instruction Dimension, ... Learning of SAP (ERP) (Kusumasari, Arini, Rajasakera, Alsolami)

structured in distance learning situations (Sun \& Hsu, 2005).

\section{Instruction Dimension will Significantly Affect Student Satisfaction}

The results of the study showed that instruction dimension significantly affect student satisfaction. The results of this study are similar to the results obtained by (Salamat et al, 2018) which showed that $86,5 \%$ students responded that e-learning makes study easier for students. In this study, the educational system quality has the greatest direct impact on student satisfaction. It could be concluded that all aspects such as collaborative between instructor and students, personalization, and environmental play major role in achieving the goal of student satisfaction.

Same result shows that ERP eLearning models provide an innovative and effective education. E-learning provide flexibility then lead to student learning satisfaction compare to ordinary learning (Dalveren, 2014).

\section{Environmental Students and Trust}

Teacher-student relationships have an impact on classroom management and affect learning progress. It is important to note that building trust and strong relationships with students is a work in progress. As teachers it is crucial that we "genuinely" care for our students and guide them as they grow, develop, and learn. Being skilled observers of students is essential in getting to know and understanding our students. Being proactive in building strong and meaningful relationships with our students and connecting with them on multiple levels is as beneficial to them as it is to us (Leitão \& Waugh, 2007).

Once trust is established, consistency is necessary. It is not simply about gaining student trust, but also being consistent in your actions and reaction in order to develop the mutual respect that is necessary to nourish and maintain a trusting teacherstudent relationship. In addition to social relationship building to enhance the student experience online, there are other factors that contribute some significant roles in student success in e-learning include cognitive complexity and intellectual stimulation (Gillet-Swan, 2017).

\section{Students Satisfaction and Trust}

The mode of communication (synchronous and asynchronous) in e-learning give opportunities to open interaction and participation for student, especially into group work activities (Gillet-Swan, 2017). The students can communicate with each other including instructor using multiple formats. Additional benefits such as the ability for both instructor and peers to offer help in timely basis, the adaptability of the environment for every individuals, and the ability for students to have a greater participatory role in the design of the learning environment, each contribute to the rationale for incorporating online learning approaches in education and as a way that both students and facilitators can better support the isolated learner (Zapalska \& Brozik, 2007).

\section{CONCLUSION}

The study investigates a model instruction dimension, environmental dimension, student trust, and student satisfaction. It is found that instruction dimension and environmental dimension positively affect student trust. The instruction dimension positively affects environmental dimension and student satisfaction. The student trust positively affects student satisfaction. It is supported as mediation between instruction dimension and environmental dimension toward student satisfaction. Regarding the theory, this study has generated new evidence of the hypothesized relationships. This study also gives new insights into how instruction dimension and environmental dimension plays role on student trust and student satisfaction at online learning.

In the future, the teaching quality or environmental quality given to students must be maintained. Because it can be seen 
from the results of the hypothesis, if the environment and lecturers provide something useful, it will increase student satisfaction and students will also be more satisfied with the material that being taught.

Another recommendation is for future research adding other variables that can prove student satisfaction, because satisfaction can be influenced by other variables that are not in this study, the influence can come from internal or external.

\section{REFERENCES}

AL-Rahmi, W., Alias, N., Othman, M. S., Alzahrani, A. I., Alfarraj, O., Saged, A. A., \& Rahman, N. S. (2018, February). Use of ELearning by University Students in Malaysian Higher Educational Institutions: A Case in Universiti Teknologi Malaysia. IEEE Access.

Ayyagari, R. (2011). Hands-on ERP Learning: Using Open ERP®, an Alternative to SAP®. Journal of Information Systems Education, 22(2), 123-133.

Bulut, S. (2019). Assessing online learners' academic self-efficacy in a symbiotic learning environment.

Chien, S.-W., \& Tsaur, S.-M. (2007). Investigating the Success of ERP System: Case Studies in Three Taiwanese High-tech Industries. Computers in Industry, 58, 783793.

Choi, D. H., Kim, J., \& Kim, S. H. (2007). ERP training with a web-based electronic learning system: The flow theory perspective. International Journal of HumanComputer Studies, 65, 223-243.

Csikszentmihalyi, M. (1990). Flow - The Psychology of optimal experience. Harper \& Row.

Dalveren, Y. (2014). Using E-Learning in Enterprise Resource Planning (ERP) Training: A Case Study to Assist Curriculum Designers in
Turkey. Procedia Social and Behavioral Sciences, 116, 13531357.

Dorobai, I., Corbea, A. M., \& Muntean, M. (2019). Integrating Student Trust in a Conceptual Model for Assessing Learning Management System Success in Higher Education: An Empirical Analysis. IEEE Access, 7, 69202-69214.

Duan, Y., He, Q., Feng, W., Li, D., \& Fu, Z. (2010). A Study on E-Learning Take-up Intention from an Innovation Adoption Perspective: A Case in China. Computers \& Education, 55, 237-246.

Engel, C. J. (2019). The Acceptability of Online Degrees in Accounting: A Literature Review. Global Journal of Business Pedagogy, 3(1), 10-26.

Gillet-Swan, J. (2017). The Challenges of Online Learning Supporting and Engaging the Isolated Learner. Journal of Learning Design, 2030.

Gray, J. A., \& DiLoreto, M. (2016, May). The Effects of Student Engagement, Student Satisfaction, and Perceived Learning in Online Learning Environments. NCPEA International Journal of Education Leadership Preparation, 11(1).

Hair, J., Black, W., Babin, B., \& Anderson, R. (2010). Multivariate Data Analysis: A Global Perspective. Pearson.

Hawking, P., \& McCarthy, B. (2001). The ERP Elearning Model for the Delivery of ERP (SAP R/3) Curriculum into the Asian Region. Informing Scienci, 257-261.

Holsapple, C. W., \& Lee-Post, A. (2006). Defining, Assessing, and Promoting E-Learning Success: An Information Systems Perspective. Decision Sciences Journal of Innovative Education, 4(1), 67-85.

Irriberri, A., Henson, J., \& Kwon, O. (2014). Integrating SAP into 
Business Curriculum: Student's Perspective on ERP's Usefulness, Ease of Use and Traning. Journal of Academy of Business and Economics, 14(4), 25-30.

Kirkham, K., \& Seymour, L. (2005). The Value of Teaching Using A Live ERP System with Resource Constraints. Proceedings of the 8th IFIP World Conference on Computers in Education (WCCE).

Krejcie, R. V., \& Morgan, D. W. (1970). Determining Sample Size for Research Activities. Educational and Psychological Measurement, 30(3), 607-610.

Ladyshewsky, R. K. (2013). Instructor Presence in Online Courses and Student. International Journal Sholarship of Teaching \& Learning, 7(1), 1-23.

Lara, J. A., Aljawarneh, S., \& Pamplona, S. (2020). Special Issue on the Current Trends in E-learning Assessment. Journal of Computing in Higher Education, 32(1), 1-8.

Lee, S. J., Srinivasan, S., Trail, T., Lewis, D., \& Lopez, S. (2011). Examining the Relationship among Student Perception of Support, Course Satisfaction, and Learning Outcomes in Online Learning. Internet and Higher Education, 14, 158-163.

Leitão, N., \& Waugh, R. (2007). Students' Views of Teacher-Student Relationships in the Primary School. Annual International Educational Research.

McIntyre, D. R., \& Wolff, F. G. (1998). An Experiment with WWW Interactive Learning in University Education. Computers Education, 31(3), 255-264.

Noorulhasan, Q., Muhammad, A., Sanober, S., Rafik, M., \& Shah, A. (2017). A Mixed Method Study for Investigating Critical Success Factors (CSFs) of E-Learning in Saudi Arabian Universities.
International Journal of Advanced Computer Science and Applications, 8(5), 171-178.

Ritchie, H., \& Newby, T. (1989). Classroom Lecture/Discussion vs. Live Televised Instruction: A Comparison of Effects on Student Performance, Attitude, and Interaction. The American Journal of Distance Education, 36-45.

Salamat, L., Ahmad, G., Bakht, M. I., \& Saifi, I. L. (2018). Effects of elearning on students' academic learning at university level. Asian Innovative Journal of Social Sciences and Humanities, 2(2), 112.

Sun, J.-n., \& Hsu, Y.-c. (2005). The Effect of Interactivity on Web-based Instruction Learners' Attitude, The Effect of Interactivity on Webbased Instruction Learners' Attitude. Proceedings of the Fifth IEEE International Conference on Advanced Learning Technologies.

Sun, P. C., Tsai, R. J., Finger, G., Chen, Y. Y., \& Yeh, D. (2008). What drives a successful e-Learning? An empirical investigation of the critical factors influencing learner satisfaction. Computers \& Education, 50, 1183-1202.

Volery, T., \& Lord, D. (2000). Critical success factors in online education. The International Journal of Educational Management, 216-223.

Webster, J., \& Hackley, P. (1997). Teaching Effectiveness in TechnologyMediated Distance Learning. Academy of Management Journal, 1282-1309.

Wilson, J. L., \& Lindoo, E. (2011). Evaluating Students' Satisfaction using Two. The Journal of Computing Sciences in Colleges, 26(4), 41-47.

Wilson, J., \& Lindoo, E. (2011). Using SAP ERP Software in Online Distance 
Education. Journal of Computing Sciences in Colleges, 26, 218-224.

Zapalska, A., \& Brozik, D. (2007).

Learning styles and online education. Campus-Wide Information Systems, 6-16. 